\title{
TRICHODINIASIS AS A CAUSE OF MORTALITY AMONG INFECTED TILAPIA ZILLII WITH SPECIAL EMPHASIS ON ITS CONTROL USING EARTHTEC ${ }^{\text {TM }}$
}

\author{
Mohamed Abdel-Meguid \\ Channel Maintenance Research Institute, National Water Research \\ Center, El Kanater, Kalubyia, Egypt.
}

Key words: Paratrichodina africana, Trichodina centrostrigeata, Tilapia zillii, gill filaments, EarthTec ${ }^{\text {TM }}$

\section{ABSTRACT}

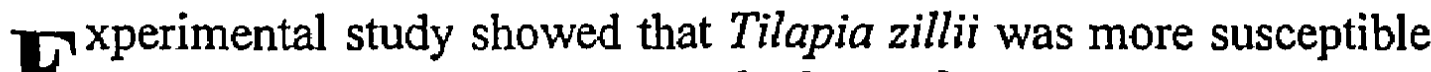
Eto the infection with Paratrichodina africana than Trichodina centrostrigeata. Heavily infected tilapia with $P$. africana died 7 days post infection, while heavily infected fish with $T$. centrostrigeata died 20 days post infection. Paratrichodina africana caused extensive epithelial proliferation, vacular degeneration, necrosis and edema, while $T$. centrostigeata caused only extensive epithelial cell hyperplasia within the gill filaments.

Long term treatments with EarthTec ${ }^{\mathrm{TM}}$ at concentrations rariged between 0.03 and $0.3 \mathrm{mg} \mathrm{Cu} /$ liter were successful in eradicating the parasite from the gill filaments.

\section{INTRODUCTION}

In Egypt, several experiments have been carried out, aiming at controlling aquatic weeds. One of those experiments is concerned with the use of the herbivorous fish Tilapia zillii for biological control of aquatic weeds specially submerged weeds. During rearing this type of fish at Delta Breeding Station (D.B.S.), the fish was subjected to many parasitic forms. Of these parasites, the ectoparasitic trichodinids are the most frequent protozoan parasites invading the gills and the skin of fishes. They are regarded as a main cause of fish mortality (Amlacher, 1970; Ahmed, 1976; Paperna, 1980; McArdle, 1984; Eisa et al., 1985; Van As and Basson, 1987; Abdel-Meguid, 1989, 1995a, b; Ramadan et al., 1995). 
Concerning the pathogenic effects of trichodinids, several investigators (Lom, 1962; Ahmed, 1976; Paperna, 1980; McArdle, 1984; Eisa et al., 1985; Van As and Basson, 1987; Abdel-Meguid, 1989, 1995a; Ramadan et al., 1995) showed that the symptoms of trichodiniasis included mainly mucus production, hyperplasia, necrosis and edema.

The present study was undertaken to evaluate the magnitude of gills injury of experimentally infected Tilapia zillii by Paratrichodina africana Kazubski and El-Tantawy, 1986 and Trichodina centrostrigeata Basson et al., 1983. Additionally, a method of control of these parasites using different concentrations of Earth Tec ${ }^{\mathrm{TM}}$ was evaluated.

\section{MATERIAL AND METHODS}

Since both parasites, $P$. africana and $T$. centrostrigeata were present on the gill filaments of naturally infected tilapia reared within ponds at D.B.S., it was decided that tilapia experimentally infected with such parasites would be used as a source of tissue for the histopathology studies. Toward that end, more than $100 \mathrm{P}$. africana and $100 \mathrm{~T}$. centrostrigeata were collected from the infected gills and inmediately stocked separately in two basins whose capacities were 2000 liters and each one contained 50 unparasitized tilapias of 8-10 grams each . The basins were provided with a source of aeration. The experiment was done at water temperature that ranged between 20 and $22 \mathrm{C}^{\circ}$. With a straight forward life cycle, the protozoan parasites could spread and infect the unparasitized population. Following the infection, heavily infected fish (that appears sluggish in their movement and wandering near the surface of water) were removed and sacrificed. The gill filaments with attached parasites were fixed in Bouin's solution, embedded in paraffin wax, sectioned at 4-5 microns and stained with haematoxylin and eosin.

To control these parasites, infected fish were subjected to different concentrations of Earth Tec ${ }^{\mathrm{TM}}$. (active ingredients: Copper sulphate pentahydrate $20 \%$, Inert ingredients $80 \%$, Metallic copper equivalent $5 \%$ ). Test solutions of EarthTec ${ }^{\mathrm{Tm}}$ were prepared using Nile water. Six different dilutions were prepared: 1:200'000 (0.3mg Cu/L), $1: 400^{\prime} 000(0.15 \mathrm{mg} \mathrm{Cu} / \mathrm{L}), 1: 500^{\prime} 000(0.12 \mathrm{mg} \mathrm{Cu} / \mathrm{L}), 1: 666^{\prime} 666$ 
Trichodiniasis as a cause of mortality among infected Tilapia 97 zillii with special emphasis on its control using Earthtec ${ }^{\mathrm{Tn}}$

(0.09mg Cu/L), 1:1'000'000 (0.06mg Cu/L), and $1: 2^{\prime} 000^{\prime} 000$ $(0.03 \mathrm{mg} \mathrm{Cu} / \mathrm{L})$. Five infected fish were used for each treatment after placing them in aquarium of 20 liters capacity provided with aeration. Samples of gill scraping were daily examined under the microscope to evaluate the infection status.

All experiments were repeated 3 times and carried out at a temperature ranging between 20 and $22 \mathrm{C}^{\circ}$.

\section{RESULTS}

The present study showed that Tilapia zillii was more susceptible to $P$. africana infection than to $T$. centrosirigeata infection. Heavily infected fish with $P$. africana died 7 days following exposure to the parasite. On the other hand, the infected fish with $T$. centrostrigeata survived the infection after 7 days post exposure and some of them died after 20 days post exposure.

Paratrichodina africana was very abundant on the gill filaments of tilapia (Fig. 1A). In heavily infected fish, an extensive epithelial cell proliferation was demonstrated. This hyperplasia extended along the whole gill filaments, resulting in fusion of the secondary gill lamellae (Fig. 2). Moreover, the comprehensive epithelial proliferation exhibited vacular degeneration, necrosis and an accumulation of edematous fluid between the secondary gill lamellae (Fig. 3). Furthermore, the parasite induced prevascular aggregation of melanin-carrying cells and inflammatory infiltration (specially lymphocytes) near the necrotic tissue (Fig. 4). In severe cases, the parasite caused a complete destruction of epithelial lining of the secondary gill lamellae, resulting in a significant decrease in the length of secondary gill lamellae (Fig. 5).

Trichodina centrostrigeata was observed among the gill filaments of tilapia (Fig.1B). In heavily infected fish, the parasite induced epithelial cell hyperplasia in the primary gill lamellae, resulting in the obliteration of the interlamellar space between the secondary gill lamellae (Fig. 6). Also, the parasite caused an epithelial cell hyperplasia among the secondary gill lamellae, as a result they were fused together and formed one unit (Fig. 7). In some cases, the epithelial cells of the secondary gill lamellae were desquamated (Fig. 8). 
Long term exposure of both protozoan parasites to 0.3. 0.15 , 0.12 and $0.09 \mathrm{mg} \mathrm{Cu} / \mathrm{L}$ was proved to be successtul in eradicating them from the gills within 24 hours. Ilowever, lower concentrations of 0.06 and $0.03 \mathrm{mg} \mathrm{Cu} / \mathrm{L}$ completely eliminated the parasites from the gills after 48 hours.

\section{DISCUSSION}

Results of the experimental study showed that tilapia was more susceptible to the infection with $P$. africana than $T$. centrostrigeata. Paratrichodina africana reduced more severely the survival rate of tilapia after 7 days post infection while the infected fish with $T$. centrostrigeata survived during that time and some of them died after 20 days post infection. This finding seems to be attributed to the size and the morphological structure of both protozoan parasites. The size of. $P$. africana is smaller than $T$. centrostrigeata (Noor El-Din and Naeim, 1998). It is generally believed that the smaller varieties of trichodinids are more pathogenic (Brown and Gratzek, 1980). This assumption coincided with what was observed among the infected tilapia. The fish severely infected with $P$. africana died first and the magnitude of the damage was more detectable on the gill filaments, although the time course to death was shorter than that among fish severely infected with $T$. centrostrigeata.

Within the gill filaments of severely infected fish with $P$. africana, the parasite induced extensive epithelial proliferation, vacular degeneration, necrosis and edema. Also, it caused complete destruction of the epithelial lining of the secondary lamellae. On the other hand, $T$. centrostrigeata induced only extensive epithelial proliferation within the gill filaments.

The present microscopical gill lesions were qualitatively similar to those previously reported on the gill filaments of fishes infected with trichodinids (Ahmed, 1976; McArdle, 1984; Eisa et al., 1985; Abdel-Meguid, 1989, 1995b; Ramadan et al., 1995). The lesions were characterized by epithelial proliferation, vacular degeneration and aggregation of melanin-carrying cells. Also, the present study showed an accumulation of inflammatory cells such as lymphocytes near the necrotic areas within the gill filaments of severely infected fish with $P$. africana. Similar host responses were reported on the gill filaments of grass carp heavily infected with Trichodinella epizootica (Abdel-Meguid, 1995b). Furthermore, the 
Trichodiniasis as a cause of mortality among infected Tilapia 99 zillii with special emphasis on its control using Earthtec ${ }^{\mathrm{Tm}}$

present study showed that $P$. africana caused complete destruction of the epithelial lining of the secondary gill lamellae and so reducing their lengths.

Copper sulphate as a - long bath treatment has been recommended to eradicate external parasites from the gills and skin of fishes (Ramadan, et al., 1995; Abdel-Meguid, 1995b, 1999; AbdelMeguid and Eure, 1996). Similarly, a trial was made in the present study to develop a control method for trichodinids, using different concentrations of EarthTec ${ }^{\mathrm{TM}}$. This compound contains a copper sulphate pentahydrate in a chelate-like "carrier". This carrier holds the copper in suspension, enabling it to stay effective at all depths. From the present results, it appears that Earth $\mathrm{Tec}^{\mathrm{TM}}$ at concentrations from 0.3 to $0.09 \mathrm{mg} \mathrm{Cu} / \mathrm{L}$ are sufficient to exterminate the protozoan parasites within 24 hours. Moreover, lower concentrations that range from 0.06 to $0.03 \mathrm{mg} \mathrm{Cu} / \mathrm{L}$ are very effective at controlling the parasites after 48 hours post exposure.

\section{REFFRENCES}

Abdel-Meguid, M. (1989). Parasitological and histopathological studies on the grass carp, Ctenopharyngodon idella raised in the Delta Breeding Station in Egypt. M. Sc.thesis, Dept. Zool. Ain Shamis Univ.

Abdel-Meguid, M. (1995a). Ectoparasite fauna of grass carp "Ctenopharyngodon idella"in Delta Breeding Station, Egypt. Vet. Med. J. Giza., 43(1):53-63. .

Abdel-Meguid, M. (1995b). Paräsitological and histopathological studies on the grasscarp,Ctenopharyngodon idella infected with Trichodinella epizootica.Vet. Med .J. Giza.,43(3):345352.

Abdel-Meguid, M. (1999). Histopathological lesions on the gill filaments of the common carp, Cyprinus carpio infested by the developmental stages of the copepod Lernaea cyprinacea Lin., with special emphasis of their control. Egypt. J. Zool. , 
Abdel-Meguid, M.and Eure, H.E. (1996). Parasitological and histopathological studies on the grass carp, Ctenopharyngodon idella Val. Infected with Trichophryapiscium. Vet. Med. J. Cairo University, Giza, $44(3): 545-550$.

Ahmed, A.T.A. (1976). Trichodiniasis of gold fish and other carp. Bangladesh J. Zool.,4:12-20.

Brown, E.E. and Gratzek, J.B. (1980). Fish farming handbook, food, biat, of tropical and gold fish. The A.V.I. publication Company, inc. Westpurt.

Eisa, M.E.; El-Shazly, H.O.; Rizk, M.H. (1980). A contribution to the pathological changes of ectoparasitic trichodinidsaffected salt water fish (Gray mullet fingerlings) in Raswa fish farms. J. Egypt. Vet. Med., 45:107-113.

Lom, J. (1962). Trichodinid ciliates from fishes of the Rumanian Black Coast. Parasitology, 52:49-61.

McArdle, J.F. (1984). Trichodina as a cause of mortalities in cage reared rainbow trout and salmon. Bull. Eur. Ass. Fish. , Path. $4: 3-6$

Noor El-Din, S. and Naeim, El-Said (1998). Cliates of the genera Trichodina, Tripartiella and Paratrichodina invading the Nile fish Clarias lazera and Oreochromis niloticus.Egypt. J. Aqat. Biol. And Fish., 2(2):35-49.

Paperna, I. (1980). Parasites infections and diseases of fish in Africa. Cifa Techincal Paper, 7.

Ramadan, N.F; El-Banhawy, M. and Abdel-Meguid, M. (1995). Trichodiniasis in the grass carp, Ctenopharyngodon idella raised in the Delta Breeding Station (D.B.S.) in Egypt. J. Egypt. Ger. Soc. Zool., 16(D):135-149.

Van As, J.G. and Basson, L. (1987). Host specificity of trichodinid ectoparasites of freshwater fish: Parasitology Today., $3(3): 88-90$. 
Trichodiniasis as a cause of mortality among infected Tilapia 101 zillii with special emphasis on its control using Earthtec ${ }^{\text {Tm }}$

\section{EXPLANATIONS OF FIGURES}

Fig. 1 (A): Photomicrograph of silver impregnated Paratrichodina africana. (X1000). (B): Photomicrograph of silver impregnated Trichodina centrostrigeata. $(\mathrm{X1000})$.

Fig. 2: Photomicrograph of a section through the gill filaments of Tilapia zillii infected with $P$. africana showing an extensive epithelial proliferation among the secondary lamellae (black arrows). Note the presence of the parasite between the secondary lamellae (white triangles). (X250).

Fig. 3: Photomicrograph of a section through the gill filaments of Tilapia zillii infected with $P$. africana showing a vacular degeneration (black arrows) and an accumulation of edematous fluid (white arrows) between the secondary lamellae. Note the presence of the parasite between the secondary lamellae (white triangles). (X250).

Fig. 4: Photomicrograph of a section through the gill filaments of Tilapia zillii infected with $P$. africana showing an aggregation of melanin-carrying cells (black arrows). (X400).

Fig. 5: Photomicrograph of a section through the gill filaments of Tilapia zillii infected with $P$. africana showing a complete destruction of epithelial lining of the secondary lamellae (black arrows). (X250).

Fig. 6: Photomicrograph of a section through the gill filaments of Tilapia zillii infected with $T$. centrostrigeata showing epithelial cell hyperplasia among the primary lamellae (black arrows). Note the presence of the parasite between the secondary lamellae (white triangles). (X250).

Fig. 7: Photomicrograph of a section through the gill filaments of Tilapia zillii infected with $T$. centrostrigeata showing fusion of the secondary lamellae (black arrows). Note the presence of the parasite between the gill filaments (white triangles). (X400).

Fig. 8: Photomicrograph of a section through the gill filaments of Tilapia zillii infected with $T$. centrostrigeata showing desquamation of the epithelial cells of the secondary lamellae (black arrows). Note the presence of the parasite between the secondary lamellae (white triangles). (X400). 


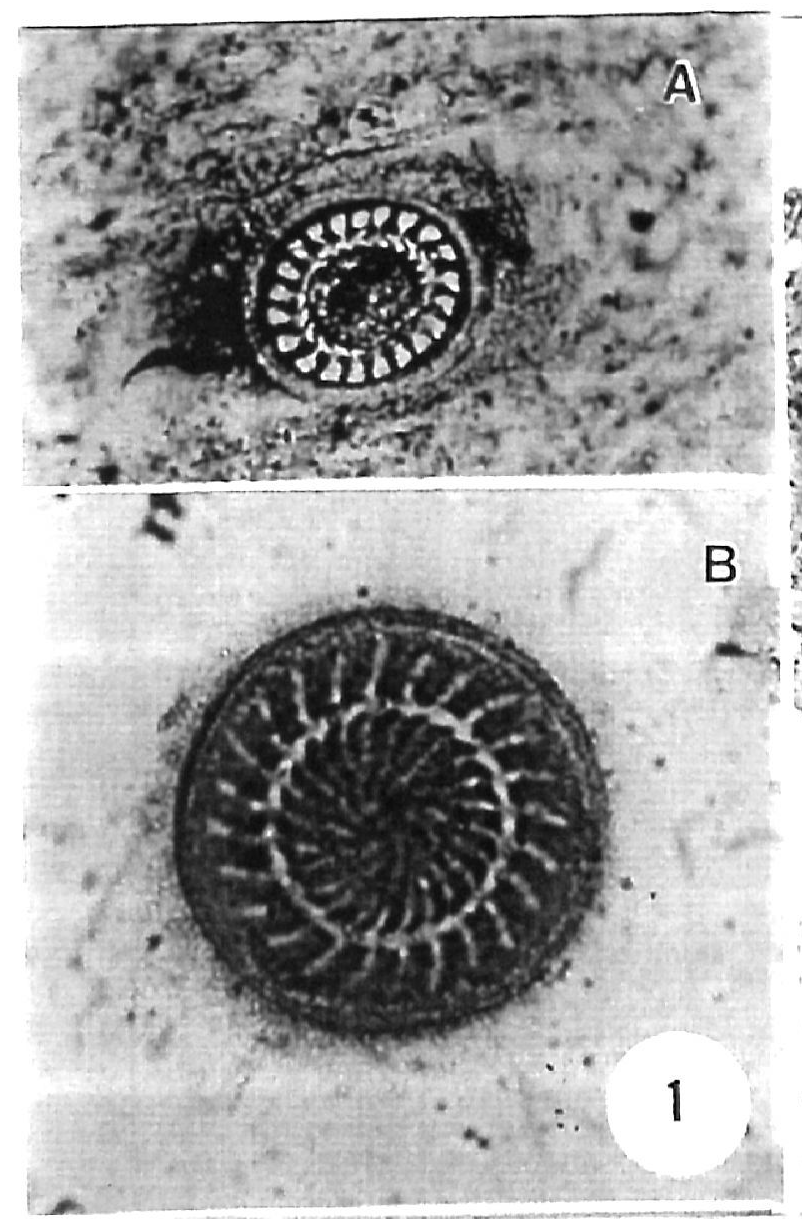

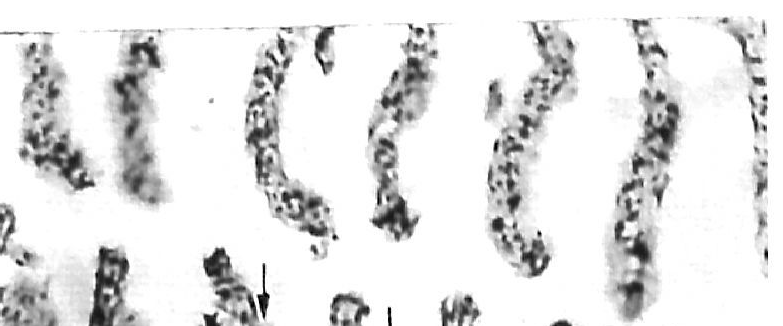

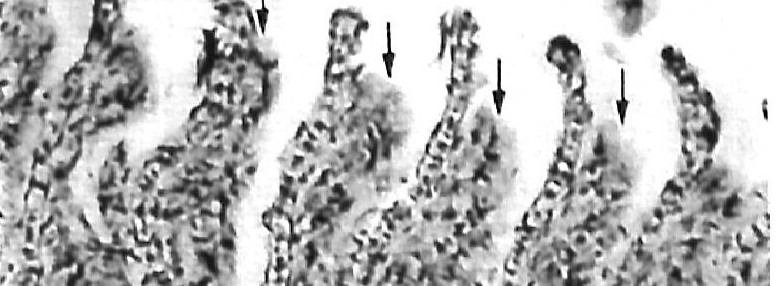

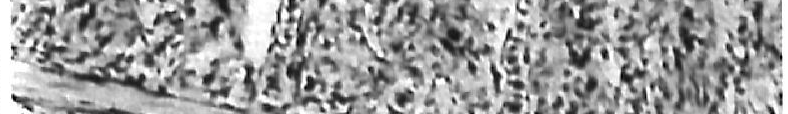

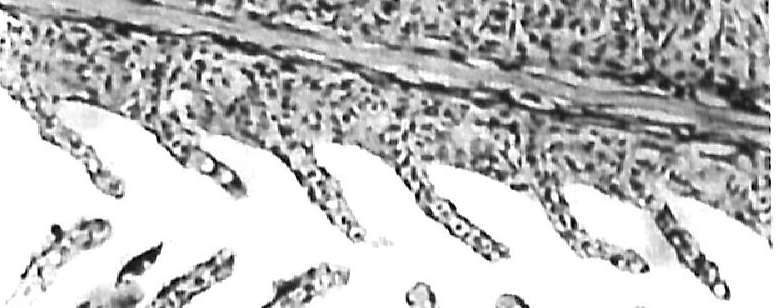

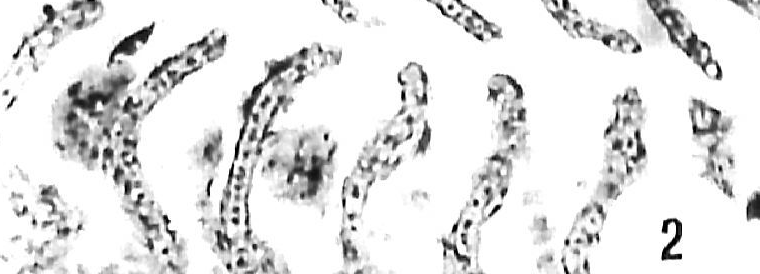

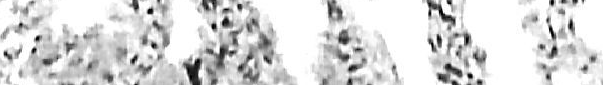

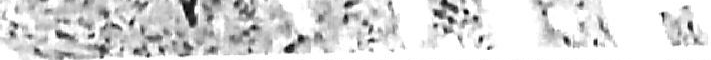

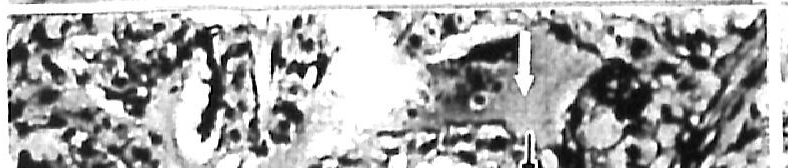

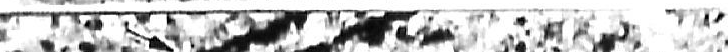

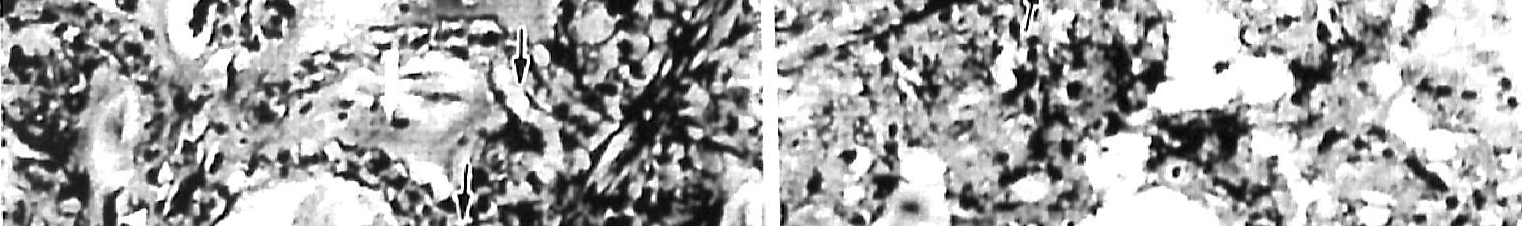

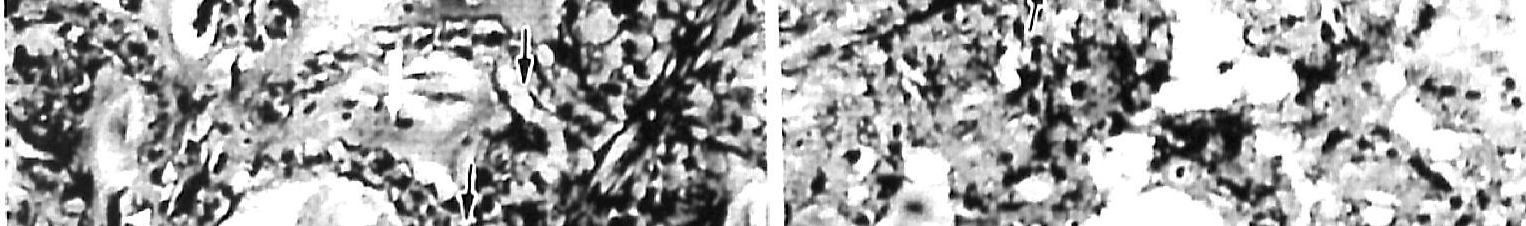

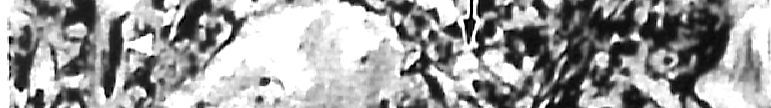
$715 \times 2$ a

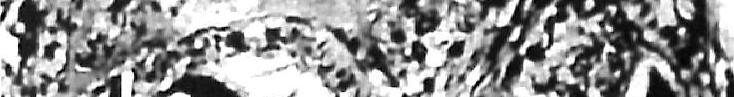

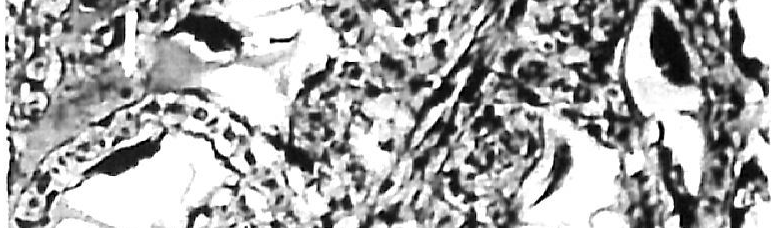

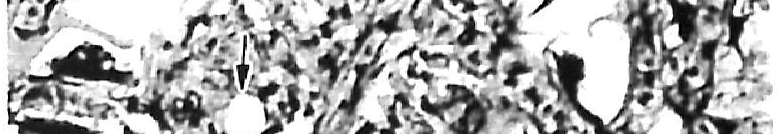

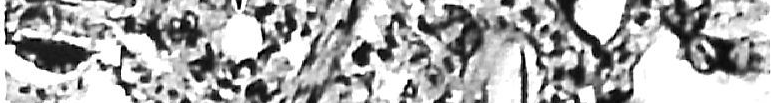

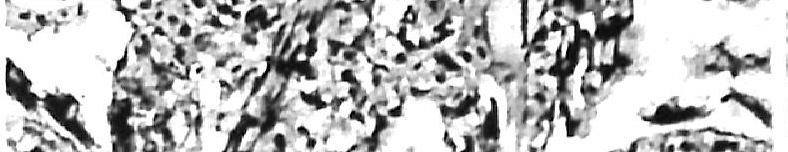

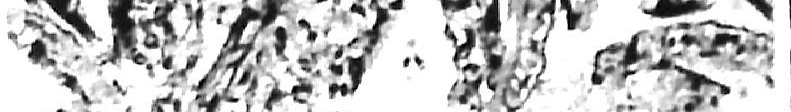

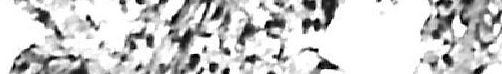
$3 \mathrm{H}^{3}$.

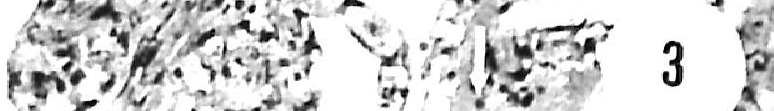
$-512+4 x^{2}+4$

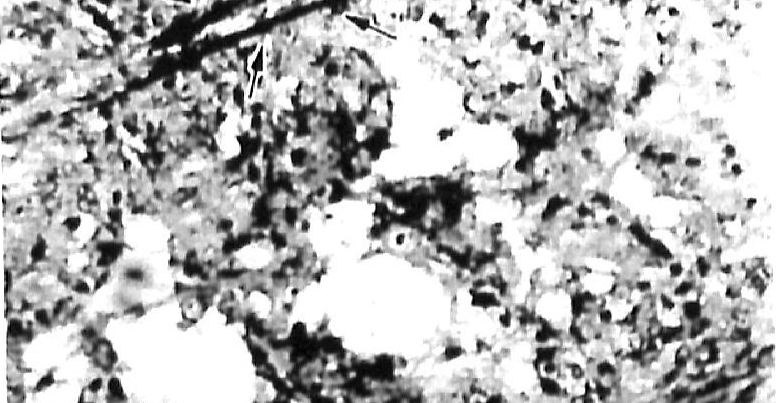

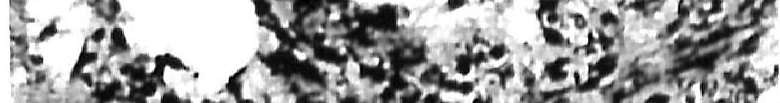

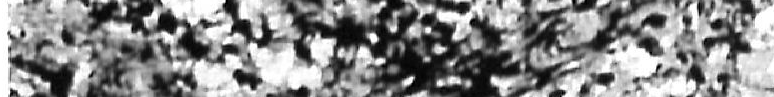

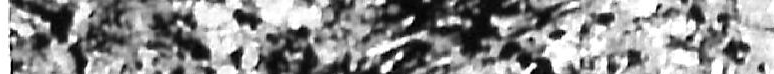

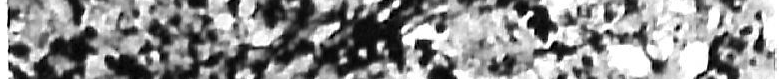

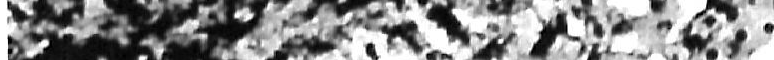

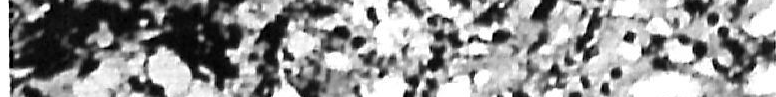

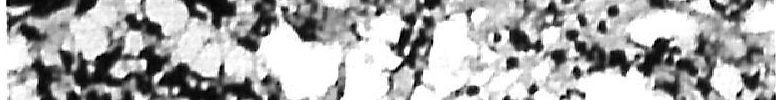

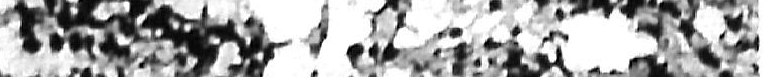

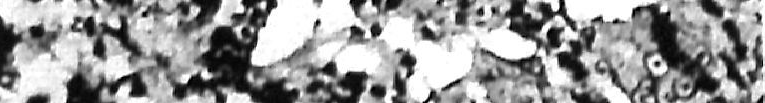




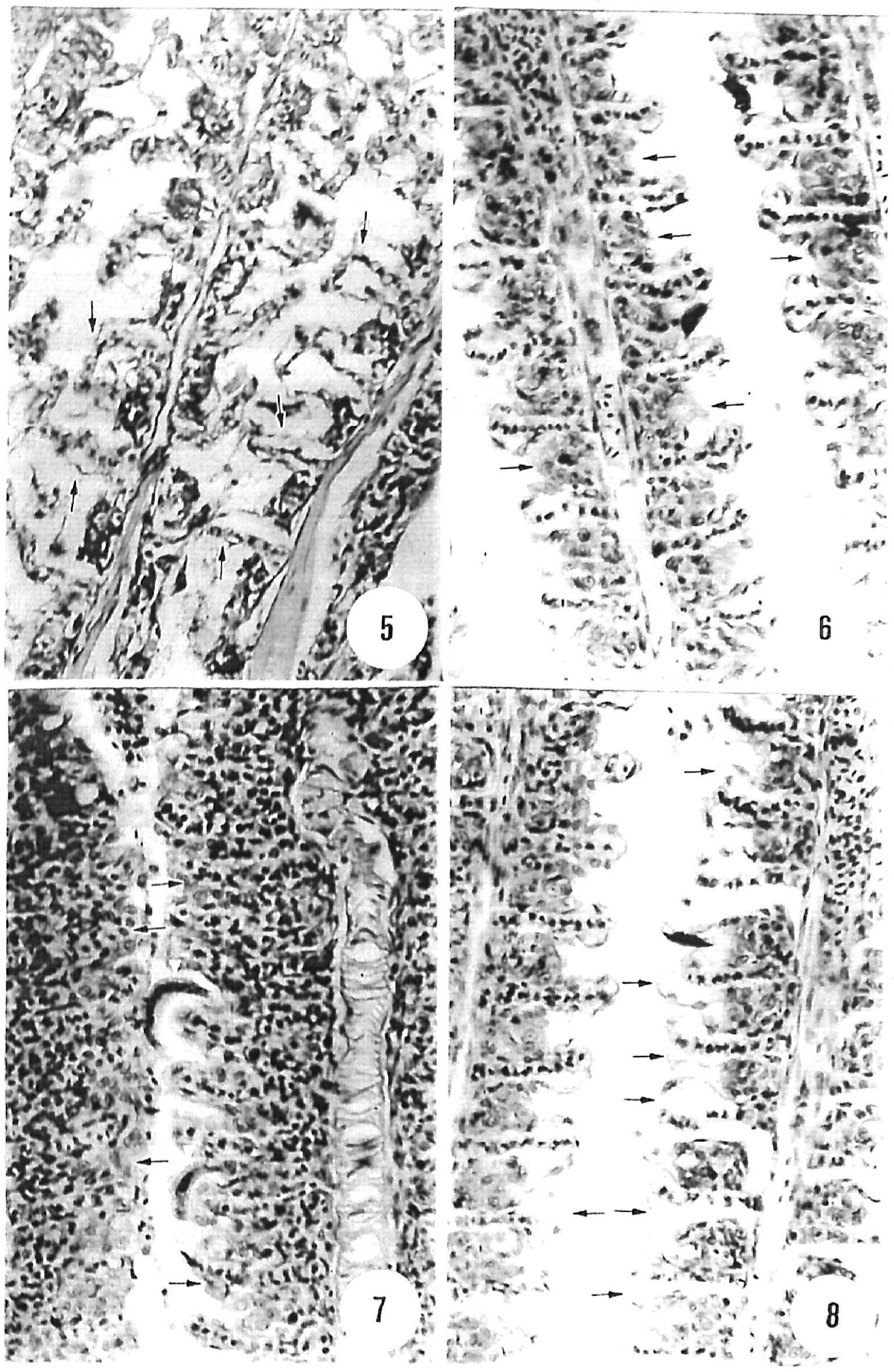

